\title{
Overexpression of the Tryptophan Cluster in Corynebacterium Glutamicum
}

\author{
Hansong Yu, Xiaodi Liu, Jiahuan Liu, Yuhua Wang, Yaohui Hu \\ College of Food Science and Engineering \\ Jilin Agricultural University \\ Changchun 130118, China \\ Email: yuhansong@163.com
}

\begin{abstract}
Extract the total DNA of HYHI, Trp cluster were cloned by PCR according to the DNA of HYHI, the length is $7100 \mathrm{bp}$. Then the gene was connect to the expression vector pZ8-1, recombinant plasmid pZ8-1-Trp cluster was obtained. The plasmid was transferred to HYHI. The positive bacteria were induced by IPTG and determination by SDS-PAGE. The consequence show that the gene cluster is expression. And the same time, anthranilic acid synthase and tryptophan synthetase activity compared with the control increased 2.4 and 3.1 times, respectively..
\end{abstract}

Keywords-Corynebacterium glutamicum; tryptophan operon; overexpression

\section{INTRODUCTION}

Tryptophan is one of the 8 kinds of human essential amino acids. With the continuous exploration of its wide application in medicine, food, livestock and other aspects, there is an urgent need for a cheaper, efficient tryptophan production method. Traditional tryptophan production methods such as chemical synthesis, protein hydrolysis and direct extraction, all the methods are not suitable for the industrialization production for their complicated procedure and high cost. Microbial and enzymatic conversion method is a future development trend, however, the tryptophan yield is not high enough with both the two methods to be a problem for research scientis $^{\mathrm{t}}{ }^{[1]}$.

With the development of recombinant DNA technology, recombinant bacteria is the effective way to solve the problem of low amino acid yield by means of gene engineering. Compared with the traditional mutation breeding technique the advantage is specific overexpression the gene of the rate limiting step of amino acid biosynthetic pathway. This study using recombinant DNA technology to clone the tryptophan synthesis key genetryptophan gene cluster, and make it over-expression in its host bacteria, increase the relative expression level of the rate limiting enzyme in order to increase the tryptophan yield finally.

\section{MATERIALS AND METHODS}

\section{A. Strains and plasmids}

Corynebacterium glutamicum HYHI; Escherichia coli DH5 $\alpha$ and Escherichia coli BL21 strain were purchased from Beijing Dingguo Biotechnology Company; pZ 8-1 shuttle expression vector was provided by Bidefeierde University joern kalinowski.

\section{B. Main reagents}

The restriction enzyme Bam HI and T4 ligase, DNA marker, STAR HS polymerase, high fidelity Prime Ex Taq enzymes were purchased from TaKaRa company; agarose gel DNA extraction kit and Plasmid Extraction Kit was purchased from Weitejie Biochemical Co., Ltd; Chorismic acid and pyridoxal phosphate were purchased from Lianxing biological company; the rest of the reagents were analytical pure grade purchased from Beijing Dingguo Biotechnology Company.

\section{PCR primers design and synthesize}

According to the GenBank published Corynebacterium glutamicum ATCC21850 tryptophan gene cluster nucleotide sequence (Gene ID No.:1018979) and pZ 8-1 prokaryotic expression vector multiple cloning sites, designed a pair of specific primers, the two primers sequence as follows: Upstream primer : P1:5'GGTGGTGGATCCGAAGGAGGACAACTTTGAGCA CGAATACCCATGTTTTCTCC-3', Downstream primer: P2:5'-GGTGGTGGATCCGAGCTAGGAGGTG GAGGCTTCTTTGTACATC-3'. The underlined part is Bam HI restriction enzyme sites, primers were synthesized by Shanghai SANGON company.

\section{PCR amplification}

The Corynebacterium glutamicum HYHI genomic DNA as template, P1, P2 as primers, amplify the Trp Cluster gene by PCR method. The reaction system is: DNA template $2 \mu \mathrm{L}, \mathrm{P} 1 \operatorname{primer}(10 \mathrm{~mol} / \mathrm{L}) 2 \mu \mathrm{L}, \mathrm{P} 2(10$ $\mathrm{mol} / \mathrm{L}) 2 \mu \mathrm{L}$, dNTP $(2.5 \mathrm{mmol} / \mathrm{L}) 4 \mu \mathrm{L}, 5 \times$ Buffer $10 \mu \mathrm{L}$, $\mathrm{ddH}_{2} \mathrm{O} 29.5 \mu \mathrm{L}$, Prime Star $0.5 \mu \mathrm{L}, 50 \mu \mathrm{L}$ total volume. The reaction conditions are as follows: $94^{\circ} \mathrm{C} 3 \mathrm{~min} ; 98^{\circ} \mathrm{C}$, $1 \mathrm{~min}, 68^{\circ} \mathrm{C}$, $8 \mathrm{~min}$. After 30 cycles, then place the sample on $72^{\circ} \mathrm{C}$ for $30 \mathrm{~min}$.

The PCR products was determinated by $1 \%$ agarose gel electrophoresis, DNA gel recovery DNA fragments, connected to T-Simple vector and transformed into Escherichia coli DH5a.After blue white screening recombinant plasmid the positive clone was sent to the Shanghai SANGON for sequencing. The above protocol come from Molecular cloning: a laboratory manual (Third Edition) ${ }^{[2]}$. 


\section{E. Construction of recombinant plasmid pZ8-1-Trp cluster}

The cloned Trp Cluster gene and pZ8-1 were digested by restriction enzyme Bam HI, and linked each other by T4 ligase. The recombinant plasmid was transformed to E. coliDH5 $\alpha$. The possible positive transformants was screened on the LB solid plate media containing kanamycin $(60 \mathrm{mg} / \mathrm{ml})$. And the PCR and enzyme digestion method was used to identify the positive clone further. An identified positive clone bacteria was sent to Shanghai SANGON Biological Engineering Technology Service Co Ltd for sequencing. The positive recombinant expression vector was named pZ8-1-Trp cluster after sequence verification.

\section{F. The recombinant plasmid pZ8-1-Trp cluster was transformed to competent cells of Corynebacterium glutamicum}

The Corynebacterium glutamicum HYHI was inoculated in $2 \mathrm{ml} \mathrm{LB}$ culture medium containing $0.5 \%$ glucose and cultured at $30^{\circ} \mathrm{C}$ and $200 \mathrm{rpm}$ for $12 \mathrm{~h}$. Then $0.5 \mathrm{ml}$ was took out from the $2 \mathrm{ml}$ and transferred into $50 \mathrm{mI}$ liquid LB culture media that including $3 \%$ glycine and $0.1 \%$ Tween 80 . Culture the mixture at $30^{\circ} \mathrm{C}$ and 200rpm until its $\mathrm{OD}_{600}$ is 0.9 . After the cell culture put the bacteria liquid on ice for $15 \mathrm{~min}$. The bacterial cell was collected by centrifuge. Wash the bacteria cell with precool $10 \%$ glycerol for 4 times. Finally suspend the cell by $0.2 \mathrm{ml} 10 \%$ glycerol and mix well after add $1-5 \mu \mathrm{L}$ DNA. Transfer the mixture into the pre-cool $0.1 \mathrm{~cm}$ electricshock cup and shock the cell in $1.8 \mathrm{kV}$ for $5 \mathrm{~ms}$. After shock $1 \mathrm{ml}$ liquid LB culture media containing $0.5 \%$ glucose was added into shock cup immediately. Mix well and transfer to $1.5 \mathrm{ml}$ microcentrifuge tube at $46^{\circ} \mathrm{C}$ for 6 $\min$ then $30^{\circ} \mathrm{C}$ for $1 \mathrm{~h}$. After water bath the mixture was concentrated to $100-200 \mu \mathrm{L}$, it was cultured at $30^{\circ} \mathrm{C}$ on $\mathrm{LB}$ solid medium containing $0.5 \%$ glucose and $35 \mathrm{~g} / \mathrm{ml}$ kanamycin by spread plate method.

\section{G. Induced expression of the recombinant bacterial contain pZ8-1-Trp cluster}

The recombinant Corynebacterium glutamicum HYHI with recombinant plasmid pZ8-1-Trp was inoculated in $1 \mathrm{ml}$ LB liquid culture media contain kanamycin $(60$ $\mathrm{mg} / \mathrm{ml}$ ) and shake at $37^{\circ} \mathrm{C}$ overnight. Take $2 \%$ form the $1 \mathrm{ml} \mathrm{LB}$ to fresh LB liquid culture media the next day and culture until the $\mathrm{OD}_{600}$ is 0.6. Add IPTG until it reach different

concentrations $(0.4,0.6,0.8,1,1.2 \mathrm{mmol} / \mathrm{L}$,respectively) and induced the different mixture at $30^{\circ} \mathrm{C}$ for $4 \mathrm{~h}$ (the control is uninduced). The bacterial cell was centrifuged at $8000 \mathrm{rpm}$ for $10 \mathrm{~min}$ from $1 \mathrm{ml}$ culture media. Then the cell was resuspended in $100 \mu \mathrm{l}$ Tris- $\mathrm{Cl}(\mathrm{pH} 8.0)$ buffer and mix with isometric $2 \times$ SDS loading buffer. Repeat boiling for $3 \mathrm{~min}$ and on ice for another $3 \mathrm{~min}$ for 3 times. Remove the cell debris by $12000 \mathrm{rpm}$ centrifuge for $10 \mathrm{~min}$. The supernatant was determinated by SDS-PAGE electrophoresis separation gel $^{[3]}$.

After induction the bacterial cell was collected by centrifuge from culture medium at $4{ }^{\circ} \mathrm{C}$. The cell was washed for 2 times with $0.1 \mathrm{~mol} / \mathrm{L} \mathrm{pH} 7.8$ Tris- $\mathrm{HCl}$ buffer. Prepare the bacteria cell suspended by adding $1 \mathrm{~g}$ wet cell in $5 \mathrm{ml}$ buffer and treat it by sonication with ice bath .The ultrasonic treatment condition is $30 \times 4 \mathrm{~s}, 200 \mathrm{~W}$. Then centrifuge the mixture for $20 \mathrm{~min}$ at $10000 \mathrm{rpm}$ and $4^{\circ} \mathrm{C}$. The supernatant is the crude enzyme solution used for determination of enzyme activity. Anthranilate synthetase and tryptophan synthetase activity determination method is according to the literature on [4] and [5].

\section{RESULT}

\subsection{PCR amplification of Trp Cluster gene}

The possible positive clones were identified by PCR method as shown in figure 1 . A $7.1 \mathrm{~Kb}$ band could be seen from the agrose gel electrophoretic picture which consistent with the expected result.

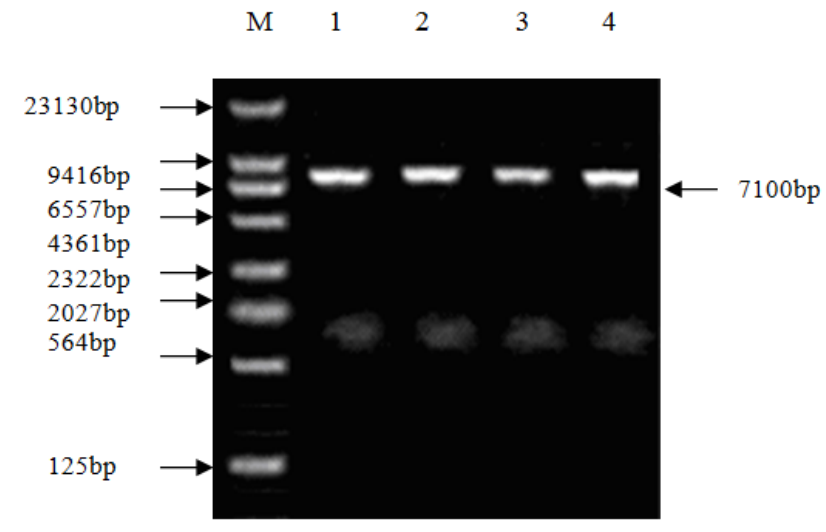

Fig1.PCR consequence of agarose gel electrophoresis 1-4:PCR product;M:marker $\lambda$-Hind III digest

\subsection{Identification of recombinant expression vector pZ8-1-Trp Cluster}

The PCR products and pZ8-1 vector were digested by Bam HI restriction enzyme at the same time and connected each other by T4 ligase. The recombinant plasmid was transformed to $E$. coli $\mathrm{DH} 5 \alpha$. The positive strain was selected by resistance screening and extract the plasmid. Then identified by restriction enzyme digestion analysis, the enzyme digestion fragment is $7100 \mathrm{bp}$ and $5493 \mathrm{bp}$, in line with the expectation theoretical sequence that can be seen from figure 2 . It was found that the gene sequence have $99 \%$ homology to ATCC21850 tryptophan cluster gene after the complete sequenced the recombinant plasmid. Therefore, it can be proved that the cloned gene is a Trp cluster gene. 


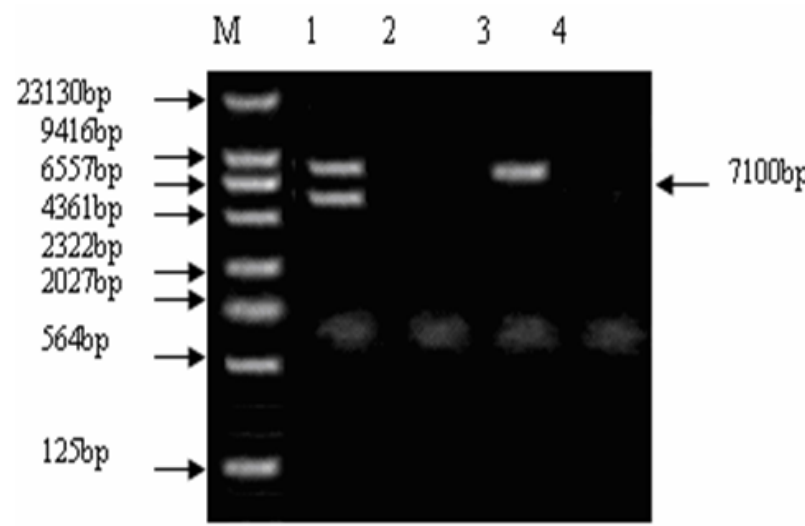

Fig2.Restriction map of recombinant plasmid M:marker $\lambda$-Hind III digest;1:pZ8-1-Trp cluster with BamHI;4 pZ8-1 with BamHI

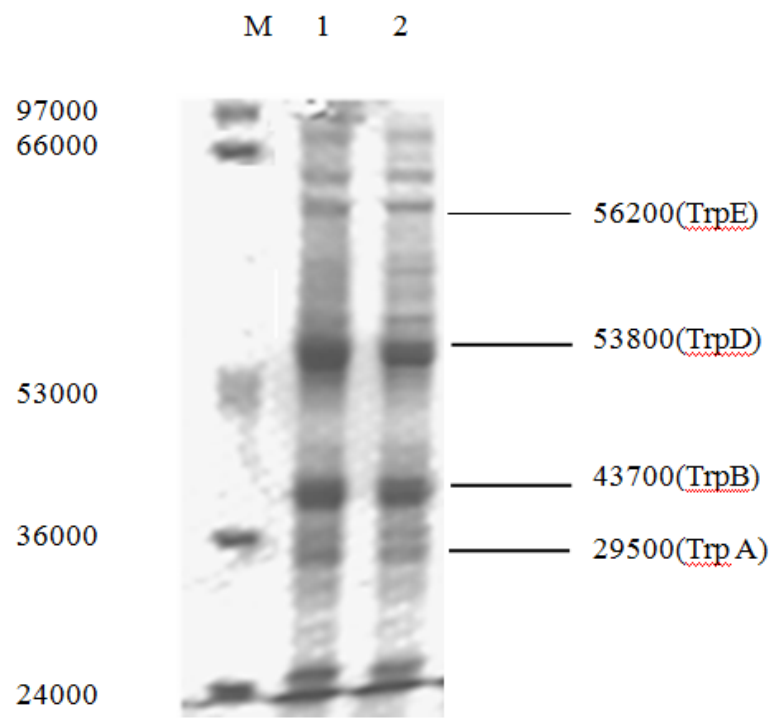

Fig 3.SDS-PAGE prolile of Trp cluster expression product in HYHI

M: protein marker; 1-2Pz8-1-trp cluster/HYHI

\subsection{Induced expression of the positive bacteria}

Induced expression the strain that contain Trp Cluster to identify whether the all the five gene can translation into protein. The Trp cluster consist of five structural gene $\operatorname{trpE}, \operatorname{trpD}, \operatorname{trpC}, \operatorname{trpB}$ and $\operatorname{trp} \mathrm{A}$, which form a polycistronic gene cluster. As can be seen from figure 3 the TrpE, TrpD, TrpB, TrpA express in recombinant strain which contain Trp cluster gene.

\subsection{Determination of the enzyme relative activity}

The enzyme relative activity of anthranilate synthase and tryptophan synthase was determinated. If the enzyme activity of host strain without recombinant Trp cluster gene is one. Then the relative enzyme activity of recombinant strain contain Trp cluster plasmid(pZ8-1-Trp cluster) is 2.4 and 3.1. The result showed in table 1 .
Tab1. Enzyme activity of anthranilate synthase and tryptophan synthase

\begin{tabular}{ccc}
\hline & \multicolumn{2}{c}{ specific activity } \\
\cline { 2 - 3 } & anthranilate synthase & tryptophan synthase \\
\hline HYHI & 1.0 & 1.0 \\
pZ8-1/ HYHI & 1.66 & 1.0 \\
pZ8-1-Trp cluster/HYHI & 2.4 & 3.1 \\
\hline
\end{tabular}

\section{DISCUSSION}

Figure 4 is the metabolic pathway of tryptophan, anthranilate synthase is the first enzyme L- tryptophan biosynthetic pathway.

The first enzyme gene and other L-tryptophan biosynthetic pathway genes form a operon and regulate by repressor system,the attenuator and feedback inhibition of L- tryptophan. And it is the key enzyme of L- tryptophan biosynthetic pathway. According to the attenuation model proposed by Yanofskv ${ }^{[6]}$ there is a DNA sequence similar to the terminator structure in the trp operon known as the attenuator. The sequence may aid regulation of transcription repression, So it may result in the expression of each protein(TrpE, $\operatorname{TrpD}, \operatorname{TrpB}, \operatorname{Trp} A)$ in this study is not very high. Jones et al. ${ }^{[7]}$ has proved that codon length of the sequence change will affect the final yield of tryptophan by experiments. In this study, the recombinant pZ8-1 vector with tryptophan operon provide new experiment material for further transformation of the regulatory sequences. It is also a foundation to improve the activity of each operon enzyme and build highyielding engineering strains. 


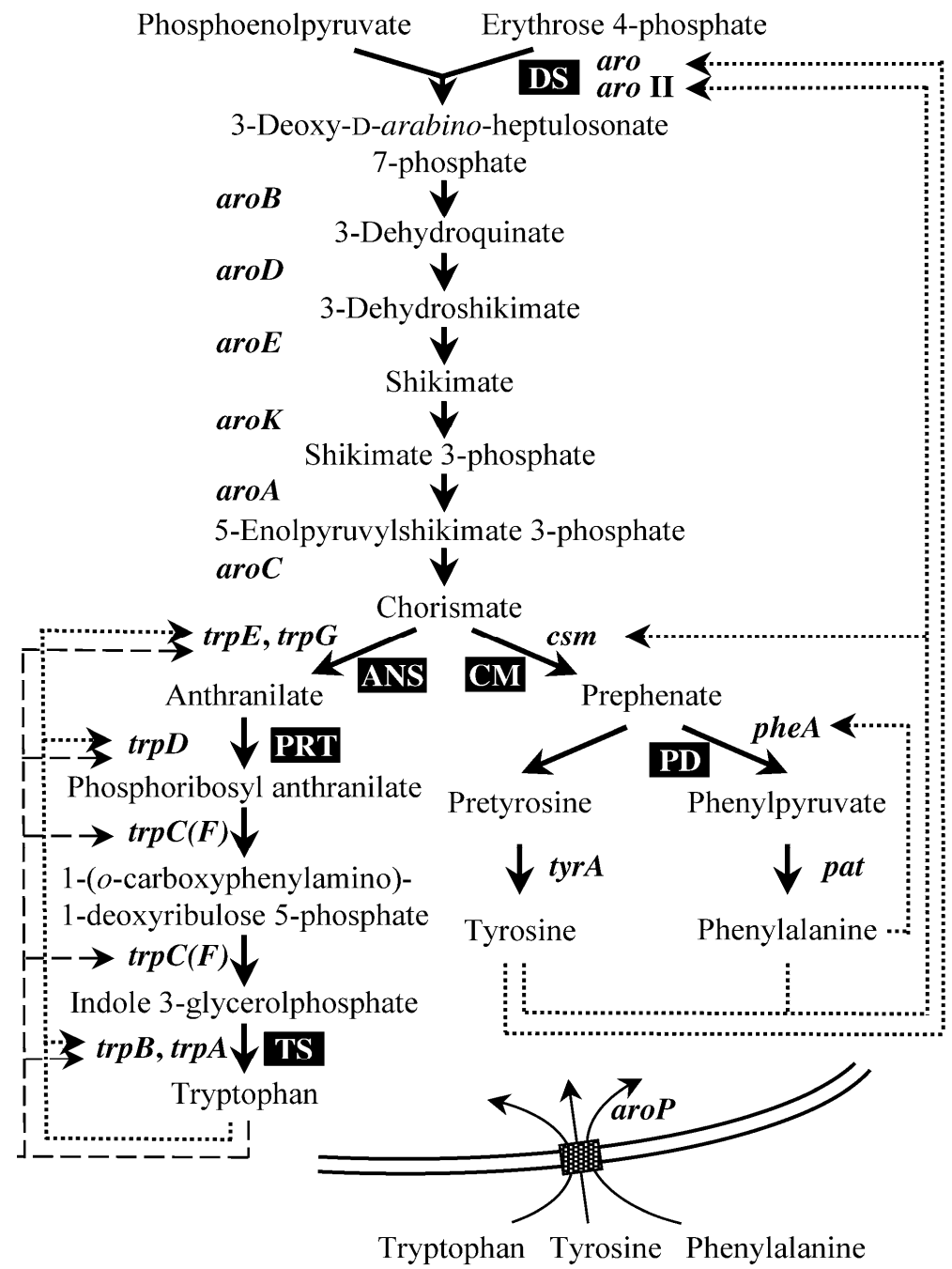

\section{ACKNOWLEDGEMENT}

The authors would like to thank the Specialized Research Fund for the Doctoral Program of Higher Education "Effect of directed evolution to improve DS activity on metabolic flux of tryptophan in Corynebacterium glutamicum (20092223110002)" for the support.

\section{REFERENCE}

[1]Tao Chen, Ning Chen. The production of L-tryptophan and breeding of tryptophan-producting strains by metabolic control, Letters in Biotechnology.2000,11(2):141-145
[2] J. Sambrook and D.W. Russell. Molecular Cloning: A Laboratory Manual (Translated by HUANG Pei-tang et al). Beijing: Science Press, 2002

[3]Ray,J.M.and Btulosonauerle,R.Purification and properties of tryptophan-sensitive 3-deoxy-D-arabino-hepate-7-phosphate synthase from Escherichia coli.[J].Bacteriol. 1991,173, 1894-1901.

[4]Shuichi A,Hiroshi I.New approach to tryptophan production by Escherichia coli;genetic manipulation of composite plasmids in viro.Appl Environ Micnobiol,1982,43(2):289-297

[5]Kasper K,Romber L W,Martha F,el al.The tryptophan synthase from Escherichia coli.Eur J Biochem,1975,60(2):513-523

[6]Yanofsky C.Attenuation as a control in gene expression.Nature.1981.289(5800):751-758

[7]James R R,Yanfsky C.The effects of leader peptide sequence and length on attenuation control of trp operon of E.coil.Nncleic Acids Res, 1991,19(4):795-800 